\title{
PENINGKATAN KAPASITAS PENGURUS DAN ANGGOTA KOPERASI BERSATU KERABAT PULO KAMBING (KBKBK) JAKARTA TIMUR PASCA KONVERSI MENJADI KOPERASI SYARIAH
}

\author{
Sahlan Hasbi ${ }^{1}$, Zaldy Suhatman ${ }^{2}$ \\ ${ }^{1}$ Program Studi Perbankan Syariah, Fakultas Ekonomi Islam, Universitas Djuanda \\ ${ }^{2}$ Program Studi Akuntansi, Fakultas Ekonomi, Universitas Pamulang \\ Email: $\underline{\text { sahlan.hasbi@gmail.com, Email: zaldy@ unpam.ac.id }}$
}

\begin{abstract}
The change in the BKPK Cooperative system from a conventional pattern to a Sharia pattern in which Islamic legal principles are an important part of the Cooperative's business activities based on fatwas has also an impact on the use of contracts in the collection of funds and in the distribution of funding. Increasing education and socialization that is more structured and systematic after the conversion is absolutely necessary as an effort to increase the competency of the human resources management and members of the Cooperative. As a manifestation of the implementation of the College's tasks, community service activities are carried out using the Pupular Education method, which is devoted to learning with the community or strengthening community abilities, potential and assets. Out of all 30 participants, only $4(13.3 \%)$ have received training on Sharia or Sharia Cooperative training. While the remaining 26 participants $(86.7 \%)$ had never attended training. The average value of the competency test results of the participants after the training, generally increased. For sharia maqasid competencies, the average pre test score was 6.67 points, an increase of $60 \%$ or the average post test score was 16.50 points. The competency value of Fatwa, Deposit Agreement and Financing during pre-test was 16.17 points, increasing by $43 \%$ or becoming 28.50 points during post-test. The competency value of the Operational Mechanism during the pre-test was 11.50 points, increasing by $55 \%$ or becoming 25.33 points during the post-test. As an accumulation of the three competencies, the average post test score of participants was 72.5 points with the lowest score being 50 points and the highest score being 95 points.
\end{abstract}

Keywords: sharia cooperative; conversion; cooperative training.

\begin{abstract}
Abstrak
Perubahan sistem Koperasi BKPK dari pola konvensional menjadi pola Syariah di mana prinsip hukum Islam menjadi bagian penting dalam kegiatan usaha Koperasi dengan berdasarkan fatwa berdampak pula pada penggunaan akad-akad dalam penghimpunan dana maupun dalam penyaluran pembiayaan. Peningkatan edukasi dan sosialisasi yang lebih terstruktur dan sistematis pasca konversi menjadi mutlak dilakukan sebagai upaya peningkatan kompetensi sumber daya manusia pengurus dan anggota Koperasi. Sebagai wujud dari implementasi tugas Perguruan Tinggi, maka dilaksanaknlah kegiatan pengabdian kepada masyarakat dengan menggunakan metode Pendidikan Masyarakat, yakni kegiatan pengabdian yang ditujukan untuk belajar bersama masyarakat atau menguatkan kemampuan, potensi dan aset masyarakat. Dari seluruh peserta pelatihan yang berjumlah 30 orang, hanya sebanyak 4 orang peserta (13.3\%) yang sudah pernah mendapatkan pelatihan tentang syariah atau Koperasi Syariah pelatihan. Sedangkan sisanya sebanyak 26 orang peserta (86.7\%) belum pernah mengikuti training. Nilai rata-rata hasil test kompetensi para peserta pasca training, umumnya mengalami kenaikan. Untuk kompetensi maqasid syariah, nilai rata-rata pre test adalah 6.67 poin mengalami kenaikan sebesar $60 \%$ atau rata-rata nilai post test adalah 16.50 poin. Nilai kompetensi Fatwa, Akad Simpanan dan Pembiayaan saat pre test adalah 16.17 poin mengalami kenaikan sebesar $43 \%$ atau menjadi 28.50 poin saat post test. Nilai kompetensi Mekanisme Operasional saat pre test adalah 11.50 poin mengalami kenaikan sebesar $55 \%$ atau menjadi 25.33 poin saat post test. Secara akumulasi dari ketiga kompetensi tersebut, nilai rata rata post test peserta adalah 72.5 poin dengan nilai terendah adalah 50 poin dan nilai tertinggi 95 poin.
\end{abstract}

Kata Kunci: koperasi syariah; konversi; pelatihan koperasi. 


\section{PENDAHULUAN}

Koperasi Bersatu Kerabat Pulo Kambing (KBKPK) yang terletak di RW 02 Kelurahan Jatinegara, Kecamatan Cakung Kota Jakarta Timur merupakan salah satu koperasi yang didirikan oleh sekelompok warga setempat dengan tujuan untuk meningkatkan kesejahteraan masyarakat sekitar. Sejak tanggal 8 Juni 2016, Koperasi Besatu Kerabat Pulo Kambing menyatakan untuk merubah sistem operasional menjadi koperasi syariah. Namun baru mendapatkan legalitas resmi pada tahun 2018 dengan akte notaris nomor 180 Tahun 2018

Perbedaan KSPPS/USPPS dengan koperasi yang menjalankan sistem konvensional terletak pada sistem operasional yang dijalankan. Di mana sistem operasional KSPPS/USPPS tidak memperbolehkan adanya konsep bunga serta tindakan praktek traksaksional lainnya yang dilarang dalam Islam seperti zalim, spekulatif, perjudian dan lain sebagainya. Koperasi Syariah sebagai bagian dari Lembaga Keuangan didirikan selain untuk kesejahteraan anggotanya juga sebagai salah satu koreksi atas koperasi konvensional yang dinilai tidak sejalan dengan prinsip-prinsip syariah (Abdurahman dan Yahya, (2015) dalam Ropi Marlina dan Yola Yunisa Pratami, 2017: 265) di mana sistem bunga yang diberlakukan di Lembaga Keuangan Konvensinal termasuk koperasi Konvensional selama ini merupakan bentuk riba yang dilarang dalam Islam. Riba merupakan segala bentuk penambahan untuk mencapai keuntungan sepihak yang terdapat dalam transaksi Lembaga Keuangan Konvensional.
Perkembangan bunga Lembaga Keuangan yang diidentikkan dengan riba dalam Islam tersebut kemudian berpengaruh buruk terhadap masyarakat, terutama masyarakat yang berada di bawah garis kemiskinan. Masyarakat mengalami kesulitan dalam mengakses dan mengembalikan pembiayaan yang telah dipinjam dari sebuah lembaga keuangan yang menerapkan sistem pengembalian berbunga tersebut. (Lasmiatun, 2013:6).

Untuk meninggalkan riba dalam praktik transaksi dilembaga keuangan konvensional, maka sebagai pilihan solusi yang dapat dilakukan oleh anggota serta para pengurus koperasi adalah dengan merubah (melakukan konversi) sistem operasional koperasi dari sistem Konvensional berbasis bunga (riba) menjadi sistem operasional berdasarkan prinsip Syariah agar dapat terhindar dari praktek-praktek ribawi. Di mana konversi dan akuisisi lembaga keuangan Konvensional menjadi Lembaga Keuangan Syariah (LKS) menjadi trend pembentukan Bank Syariah di tahun 2008 (Abdul Ghafur Anshari: 2010) dan menjadi salah satu upaya yang dapat ditempuh untuk meningkatkan asset LKS di Indonesia secara lebih cepat.

Perubahan sistem Koperasi BKPK dari pola konvensional menjadi pola Syariah di mana prinsip hukum Islam menjadi bagian penting dalam kegiatan usaha Koperasi dengan berdasarkan fatwa yang dikeluarkan oleh Dewan Syariah Nasional Majelis Ulama Indonesia berdampak pula pada penggunaan akad-akad dalam 
penghimpunan dana maupun dalam penyaluran pembiayaan.

Sejak Koperasi BKPK melakukan konversi menjadi koperasi syariah, mayoritas pengurus dan anggota koperasi belum pernah mendapatkan training tentang perkoperasian syariah, baik terkait aspek pendanaan maupun aspek pembiayaan. Kondisi ini dapat berdampak pada ketidakmampuan pengurus untuk mengelola koperasi syariah secara profesional serta dapat terjebak dalam praktek ribawi yang dilarang oleh agama Islam.

Faktor kritis pengelolaan Koperasi salah satunya terletak pada unsur sumber daya manusia (SDM), di mana pengelolaan Koperasi perlu ditangani secara profesional karena membutuhkan keahlian khusus yang membutuhkan spesialisasi untuk melakukan pengelolaan keuangan yang rigit. Kondisi tersebut sangat riskan jika kompetensi SDM yang akan mengelola Koperasi syariah tidak dibekali dengan kompetensi yang memadai baik dari aspek manajerial maupun aspek syariah, sehingga besar kemungkinan tidak dapat bersaing dalam mengahadapi kompetisi dengan lembaga keuangan lainnya.

Bagi pengurus Koperasi Syariah yang baru melakukan konversi/baru berdiri, setidaknya membutuhkan tambahan pengetahuan bagaimana penerapan akad-akad simpanan dan pembiayaan syariah serta mekanisme operasional koperasi berbasis syariah. Sementara itu, pengabdian yang berkaitan dengan upaya peningkatan kompetensi sumber daya manusia pengurus dan anggota koperasi pasca konversi ke syariah sangat jarang dilakukan.

Peningkatan edukasi dan sosialisasi yang lebih terstruktur dan sistematis pasca konversi tersebut bukan hanya menjadi tugas internal pemangku kepentingan koperasi syariah, namun harus juga menjadi bagian tugas yang harus dijalankan oleh dosen-dosen Perguruan Tinggi yang membuka program studi kajian ekonomi syariah dengan cara melakukan pendampingan implementasi prinsip syariah sebagai bagian dari program pengabdian kepada mayarakat.

\section{METODE PELAKSANAAN}

Kegiatan PKM dilaksanakan pada tanggal 10 Agustus 2019 di Kantor Koperasi Bersatu Kerabat Pulo Kambing (KBKPK) yang terletak di RW 02 Kelurahan Jatinegara, Kecamatan Cakung Kota Jakarta Timur dengan menggunakan metode Pendidikan Masyarakat (popular Education), yakni kegiatan pengabdian yang ditujukan untuk belajar bersama masyarakat atau menguatkan kemampuan, potensi dan aset masyarakat. Metode Pendidikan Masyarakat ini diselenggarakan dengan pola explicit instruction atau pengajaran langsung dan tanya jawab dengan melibatkan peran aktif semua elemen yang terlibat dalam pelatihan.

Materi yang diberikan adalah: (1) Latar belakang pentingnya keuangan inklusif, (2) Pembentukan Istilah Lembaga Keuangan Syariah (3) Maqasid Syariah, (4) Akad-akad dan Mekanisme Operasional di Koperasi Syariah, (5) Transaksi- Transaksi Terlarang di Lembaga Keuangan Syariah. 
Output yang dihasilkan dari Pelatihan Peningkatan Kapasitas Pengurus dan Anggota Koperasi Bersatu Kerabat Pulo Kambing Pasca Konversi menjadi Koperasi Syariah adalah berupa peningkatan pengetahuan dan keterampilan Pengawas, Pengurus dan Anggota Koperasi Bersatu Kerabat Pulo Kambing terkait:
1. Koperasi Syariah dan konvensional

2. Fatwa-fatwa DSN MUI

3. Akad Pembiayaan dan Simpanan BerbasisSyariah.

4. Mekanisme Operasional Koperasi Syariah

Tahapan kegiatan pengabdian ini akan dijelaskan melalui bagan berikut:

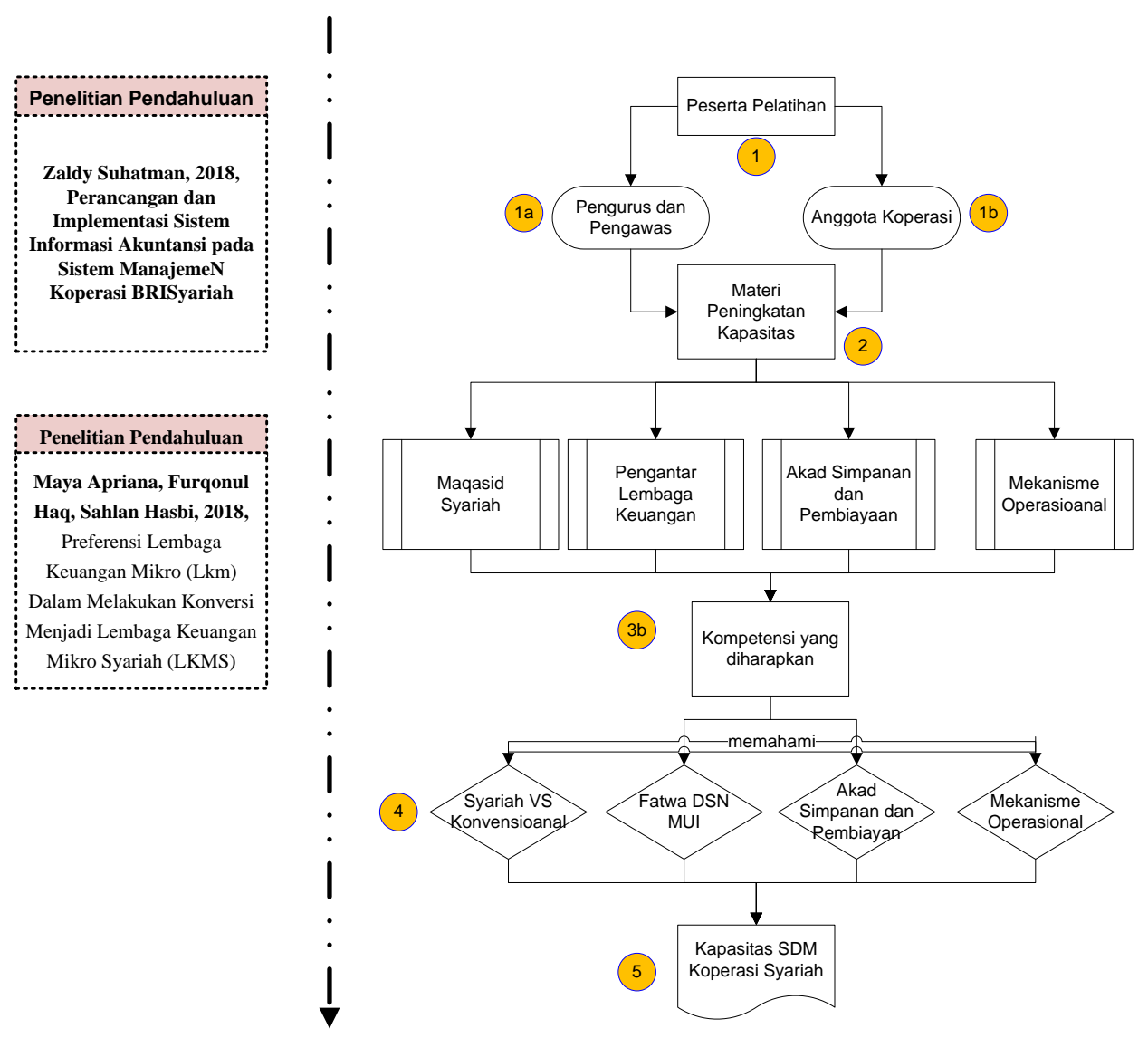

Gambar 1. Alur Proses Pelaksanaan Program Kemitraan Masyarakat (PKM).

\section{HASIL DAN PEMBAHASAN}

a. Pengalaman Peserta dalam Mengikuti Pelatihan Tentang Koperasi Syariah

Peserta pelatihan yang sudah pernah mengikuti Pelatihan Tentang Koperasi Syariah cukup minim. Dari seluruh peserta pelatihan yang berjumlah 30 orang, hanya sebanyak 4 orang peserta
(13.3\%) yang sudah pernah mendapatkan pelatihan tentang syariah atau Koperasi Syariah pelatihan.

Sedangkan sisanya sebanyak 26 orang peserta $(86.7 \%)$ belum pernah mengikuti training. Hal ini mengindikasikan bahwa training terkait koperasi syariah dalam rangka mengupayakan peningkatan kapasitas 
pengurus dan anggota Koperasi Bersatu

Timur pasca konversi menjadi koperasi Kerabat Pulo Kambing (KBKPK) Jakarta syariah mutlak dilakukan.

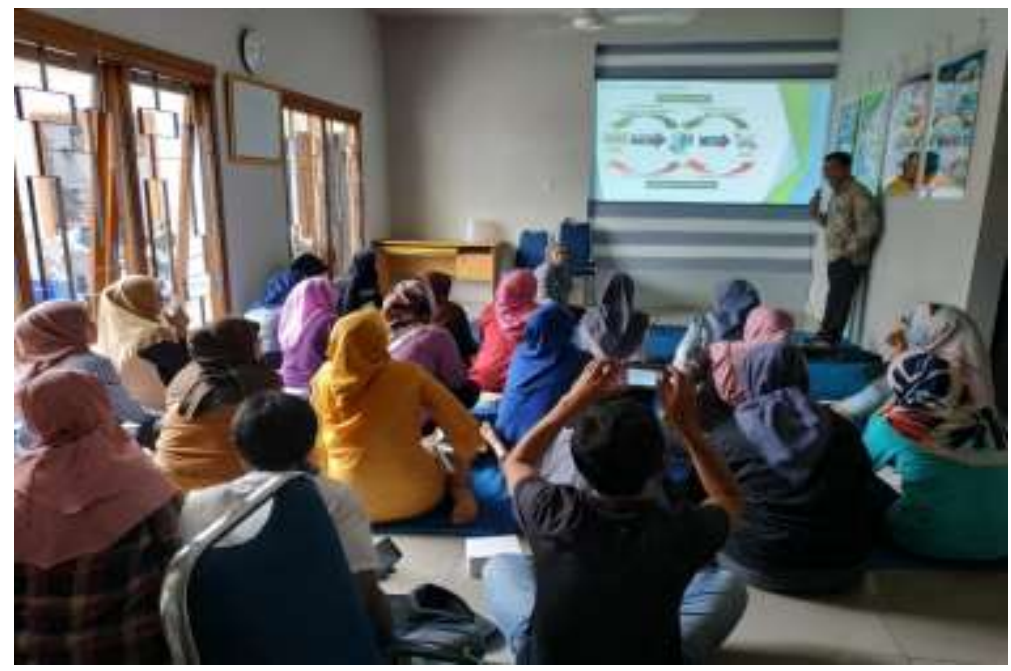

Gambar 2. Suasana Pelatihan Peningkatan Kapasitas Pengurus dan Anggota Koperasi Bersatu Kerabat Pulo Kambing (KBKPK)

\section{b. Kompetensi Peserta Pra dan} Pasca Training.

Output yang dihasilkan dari Pelatihan Peningkatan Kapasitas Pengurus dan Anggota Koperasi Bersatu Kerabat Pulo Kambing Pasca Konversi menjadi Koperasi Syariah adalah berupa peningkatan pengetahuan dan keterampilan Pengawas, Pengurus dan Anggota Koperasi Bersatu Kerabat Pulo Kambing terkait: (1) Kompetensi Maqasid syariah, 2) Kompetensi Fatwa, Akad Simpanan dan Pembiayaan
(3) Kompetensi mekanisme Operasional Koperasi Syariah.

Uji Kompetensi Maqasid syariah bertujuan untuk mengukur kemampuan peserta pelatihan mengenai hukum asal transaksi muamalat, tujuan akad serta konsep riba dalam Islam, yang terdiri dari 5 buah soal pilihan ganda. Secara rinci hasil uji Kompetensi Maqasid syariah para peserta pelatihan, baik pre test maupun post test dapat dilihat pada Gambar 3 berikut:

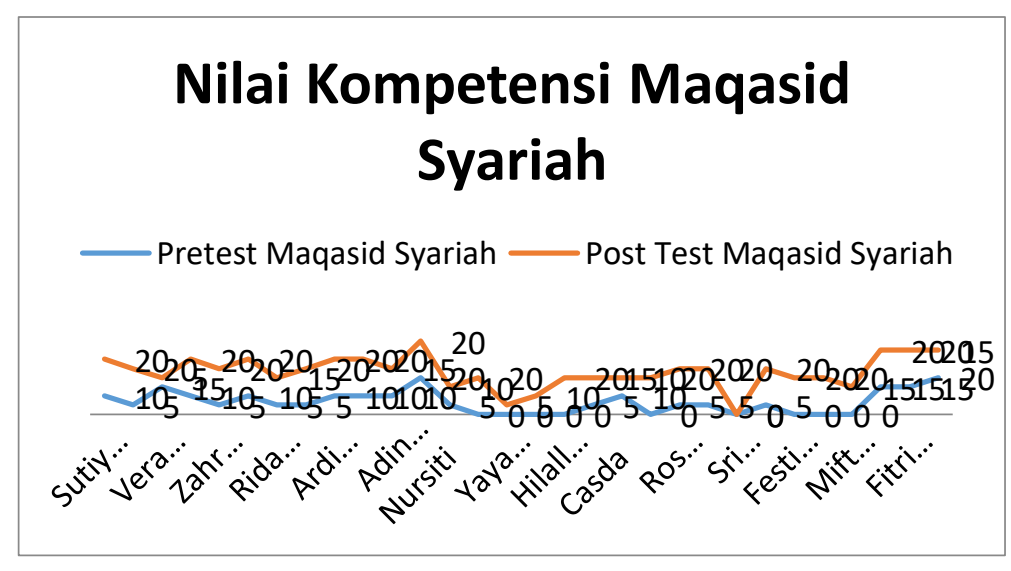

Gambar 3. Nilai Kompetensi materi Maqasid Syariah 
Nilai rata-rata hasil test kompetensi para peserta pada bidang maqasid syariah umumnya mengalami kenaikan. Nilai rata-rata pre test adalah 6.67 poin mengalami kenaikan sebesar $60 \%$ atau rata-rata nilai post test menjadi 16.50 poin dengan rentang nilai baik pre test maupun post test adalah $0-20$ poin.

Soal yang diujikan untuk mengukur Kompetensi Fatwa, Akad Simpanan dan Pembiayaan terdiri dari 8 soal pilihan ganda yang difokuskan pada pokok bahasan terkait jenis-jenis akad produk pembiayaan maupun pendanaan di Koperasi Syariah serta ragam transaksi yang boleh dan terlarang berdasarkan fatwa yang dilengkapi dengan contoh kasus yang sering terjadi. Secara rinci hasil uji Kompetensi Fatwa, Akad Simpanan dan Pembiayaan para peserta pelatihan, baik pre test maupun post test dapat dilihat pada Gambar 4 berikut:

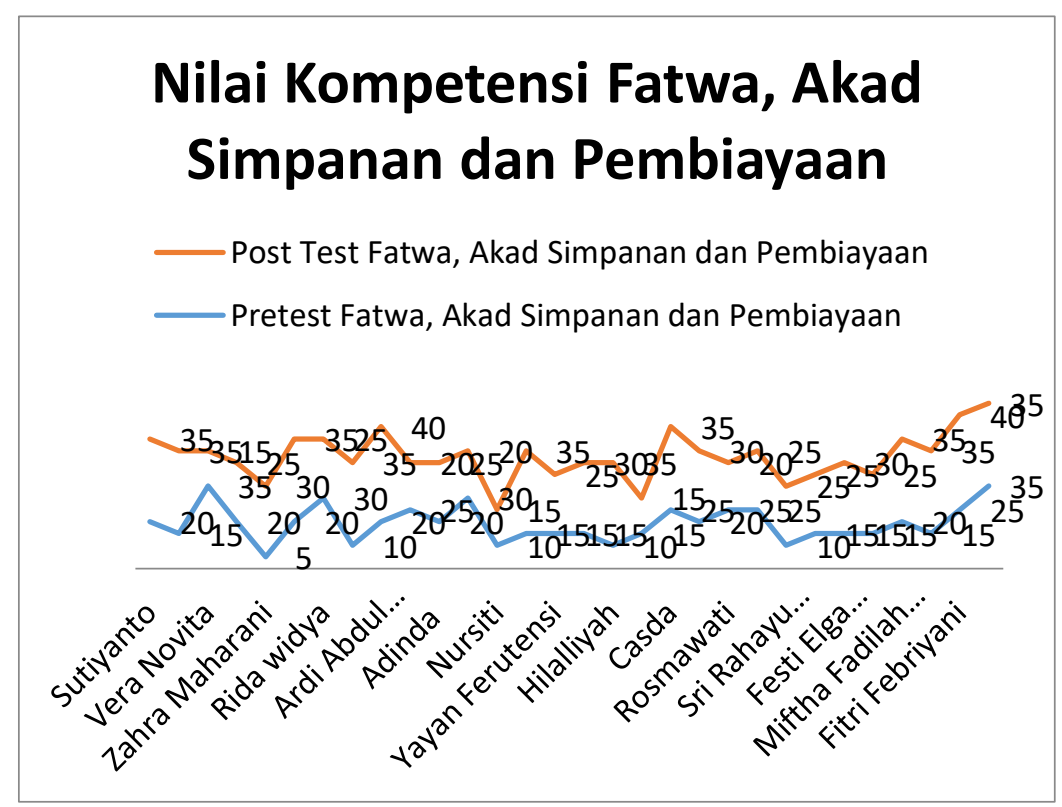

Gambar 4. Nilai Kompetensi Materi Fatwa, Akad Simpanan dan Pembiayaan

Nilai rata-rata kompetensi peserta pelatihan pada bidang Fatwa, Akad Simpanan dan Pembiayaan saat pre test dilaksanakan adalah sebesar 16.17 poin dengan rentang nilai 5 - 30 poin, dan mengalami kenaikan sebesar $43 \%$ atau menjadi 28.50 poin saat post test dilaksanakan dengan rentang nilai 15 40 poin.

Sedangkan Soal yang diujikan untuk mengukur Kompetensi mekanisme Operasional Koperasi
Syariah terdiri dari 7 soal pilihan ganda yang bertujuan untuk mengukur kemampuan peserta pelatihan mengenai mekanisme transaksi di koperasi syariah, penjaminan, agunan, maupun hal lainnya yang terkait dengan masalah operasional. Secara rinci hasil uji kompetensi Mekanisme Operasional Koperasi Syariah para peserta pelatihan, baik pre test maupun post test dapat dilihat pada Gambar 5 berikut: 


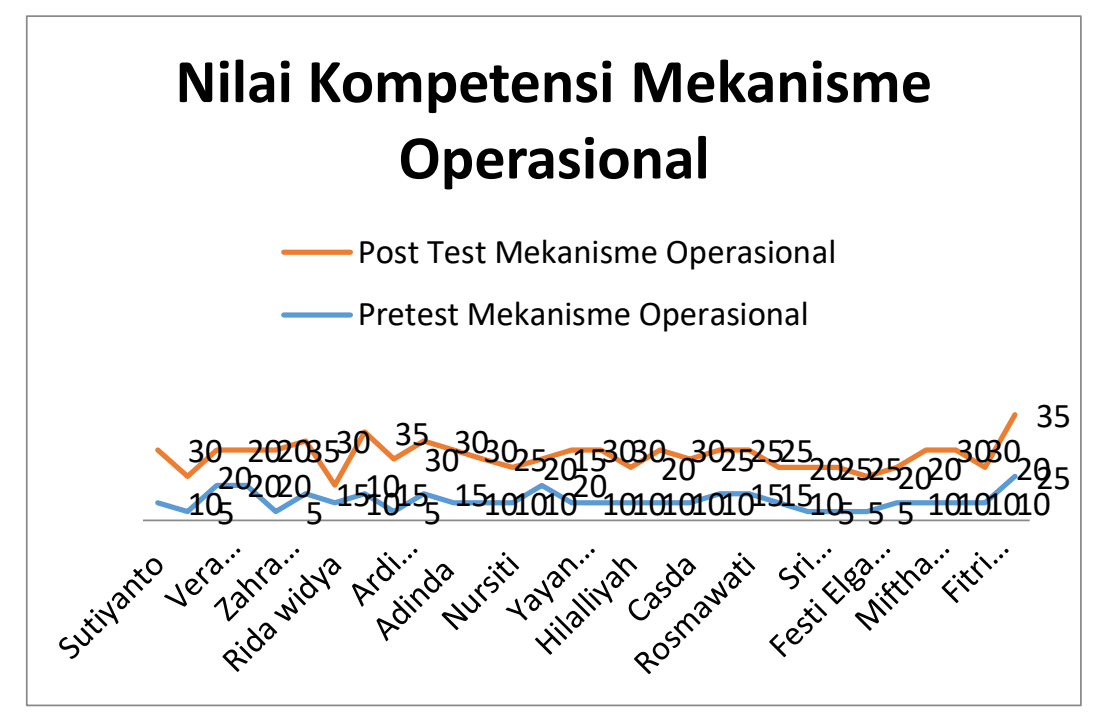

\section{Gambar 5. Nilai Kompetensi Materi Mekanisme Operasional}

Nilai rata-rata kompetensi peserta pelatihan pada bidang Mekanisme Operasional saat pre test dilakukan adalah 11.50 poin dengan rentang nilai 5 - 25 poin, dan mengalami kenaikan sebesar $55 \%$ atau menjadi 25.33 poin saat post test dilakukan dengan rentang nilai $10-35$ poin

Nilai rata-rata hasil evaluasi untuk setiap materi baik saat pre test maupun post test dapat dilihat secara rinci pada gambar 6 berikut:

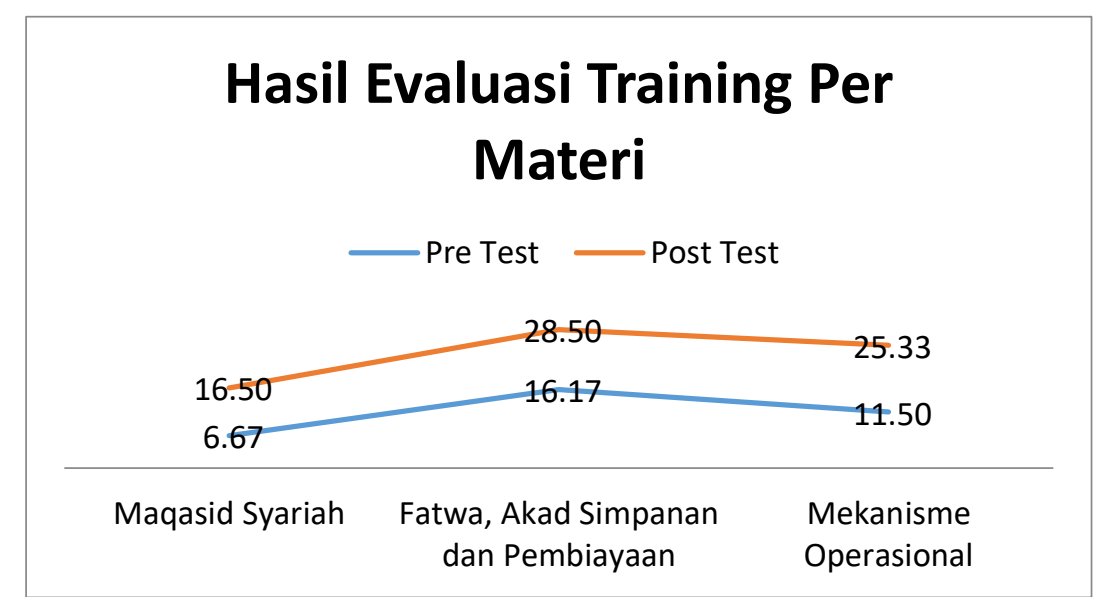

Gambar 6. Hasil Evaluasi Per Materi Training

Secara akumulasi nilai rata-rata ketiga kompetensi tersebut pada saat post test adalah 72.5 poin dengan nilai terendah adalah 50 poin dan nilai tertinggi adalah 95 poin. Kondisi ini
menunjukkan
terdapat peningkatan pengetahuan dan keterampilan peserta pasca mengikuti pelatihan koperasi syariah. 


\section{PENUTUP}

Berdasarkan hasil pengabdian masyarakat yang bertujuan untuk meningkatkan Kapasitas Pengurus dan Anggota Koperasi Bersatu Kerabat Pulo Kambing Pasca Konversi menjadi Koperasi Syariah membuahkan hasil yang cukup bagus. Kondisi ini terlihat dari peningkatan pengetahuan dan keterampilan para peserta pelatihan yang tercermin pada nilai rata-rata post test secara akumulatif atas Kompetensi Maqasid syariah, Kompetensi Fatwa, Akad Simpanan dan Pembiayaan serta Kompetensi mekanisme Operasional Koperasi Syariah pasca mengikuti pelatihan mencapai nilai 72.5 poin. Untuk menjaga kualitas kompetensi pengurus dan anggota, pelatihan serupa selayaknya dilakukan secara simultan dan terjadwal.

\section{DAFTAR PUSTAKA}

Anshari, Abdul Ghafur. 2010. Konversi Bank Konvensional Menjadi Bank Syariah Ditinjau dari Hukum Postif dan Hukum Islam. Sumedang: UPI Sumedang Press.

Apriyana, Maya, Furqonul Haq, dan Sahlan Hasbi. 2018. Preferensi Koperasi Dalam Melakukan Konversi Menjadi Koperasi Syariah (Studi Kasus Pada Koperasi Di Wilayah Bogor). Bogor Unida. (skripsi).

Er, Bünyamin And Mesut Mutlu. 2017. Financial Inclusion and Islamic Finance: A Survey of Islamic Financial Literacy Index. International Journal of Islamic Economics and Finance Studies.
Khairina, Syifa. 2017. Analalisi Preferensi UMKM terhadap Pembiayaan Syariah di Kota Depok. Institut Pertanian Bogor: Bogor.

Lasmiatun. 2013. Prospek Lembaga Keuangan Mikro Syariah Dalam Mendukung Pembiayaan Usaha Berskala Mikro Untuk Pengentasan Kemiskinan Di Indonesia. Dharma Ekonomi STIE Dharmaputra. No. 37 / Th XX / April.

Makhijani, Dyah N.K. 2010. Bank Indonesia Dorong Inovasi Produk Syariah Berstandar Internasional Melalui Pertemuan ke-23 Dewan Direktur International Islamic Financial Market (IIFM). Biro Hubungan Masyarakat Direktorat Perencanaan Strategis dan Hubungan Masyarakat Bank Indonesia: Jakarta.

Marlina, Ropi dan Yola Yunisa Pratami. 2017. Koperasi Syariah Sebagai Solusi Penerapan Akad Syirkah Yang Sah. Amwaluna: Jurnal Ekonomi dan Keuangan Syariah Vol. 1 No.2 (Juli, 2017), Hal 263275

Najib, Haifa dan Rini. 2016. Sharia Compliance, Islamic Corporate Governance Dan Fraud Pada Bank Syariah. Jurnal Akuntansi dan Keuangan Islam Vol. 4, No. 2 (2016)

Qurbani, Dani. 2015. Analisis Kinerja Koperasi Simpan Pinjam Berbasis Syari'ah Di Kabupaten Magelang 
Tahun

2011-2013.

Yogyakarta: UNY Press.

Rahayu, Sri. 2015. Kontribusi Lembaga Keuangan Mikro Syariah Terhadap Pemberdayaan Perempuan (Studi Kasus BMT di Kabupaten Sleman Yogjakarta). Jurnal Inovasi dan Kewirausahaan. Vol 4 N.3.

Rahim, et al. 2016. Islamic Financial Literacy and its Determinants among University Students: An Exploratory Factor Analysis. International Journal of Economics and Financial Issues | Vol 6. Special Issue (S7).

Suhatman, Zaldy. 2018. Perancangan dan Implementasi Sistem Informasi Akuntansi pada Sistem Manajemen Koperasi BRIsyariah. Jurnal Ilmiah Akuntansi Universitas Pamulang Vol 5. 